\title{
Relationship Between Primary School Pupils Performance in Art and Science in Sokoto, Nigeria
}

\author{
Muhammad, R,* Kamar, $\mathbf{Y} *$ and Ibrahim, N. T** \\ *Department of Science and Vocational Education, Usmanu Danfodio University, Sokoto-Nigeria \\ **Department of Biology, Shehu Shagari College of Education, Sokoto-Nigeria
}

\section{Doi:10.5901/jesr.2013.v3n4p115}

\begin{abstract}
The study was on the relationship between primary school pupils performance in Cultural and Creative Art (CCA) and in Basic Science and Technology (BST) in Sokoto state. Primary science is taught in the primary school as a core subject, as such it has been of interest to researchers and stake holders to raise the standard of children performance and achievement in science in primary school. Correlational research design was adopted in the conduct of these research. 360 children were sampled from 12 primary schools for the study through the four State Universal Basic Education Board (SUBEB) zones in Sokoto state. Two instruments were developed by the researcher in BST and CCA, which were validated by experts and found reliable at 0.86 and 0.78 respectively. Pearson $\boldsymbol{r}$ was employed in the analysis of data hypothesis was formulated and tested at .05 level of significance. Result showed that there is significant relationship between primary school pupils performance in BST and in CCA in Sokoto state. As a recommendation, relevant authorities such as inspectors, supervisors and other education regulatory agencies should monitor the trend in relationship and difference of performance of primary school pupils in $B S T, C C A$ and such other subjects taught at primary school. The researchers suggests that further research should be carried out on causation of relation between BST, CCA and such other subjects taught in the primary school.
\end{abstract}

Key Words:- Relationship, Primary, Performance, Art and Science

\section{Introduction}

Science and its application are the foundation of economic and industrial development of the world. The effect of science and technology on industrial revolution cannot be overemphasized. The Federal Government of Nigeria (FGN) attempt to attain the Millennium Development Goals (MDGs) by 2015 , and by extension the need to implement the National Economic and Empowerment Development Strategy (NEEDS), which is summarized in the Preface of the National Educational Research and Development Council (NERDC,2007), prompted the National Council on Education (NCE) to approve a new curriculum structure with subjects listing that include Basic Science and Technology (BST) and Cultural and Creative Art (CCA). Primary education, as referred to in the Federal Republic of Nigeria (FRN)National Policy on Education (2004), is the education given in institutions for children aged 6 to $11^{+}$.

Young (1979) affirmed science as an important subject for the primary school. Ibrahim (2000) described Art as means of: 'Beautification/Decoration (body and environment); Livelihood i.e. provides vocation / employment opportunities, career, foreign exchange etc; Entertainment /Aesthetic satisfaction; Universal language; Communication /illustrations, among others'. These are all integral parts of science. Primary Science now known as Basic Science and Technology (BST) and Art now known as Cultural and Creative Art (CCA) are taught in the primary school in Nigeria 
and most other countries, and through tertiary level in a more specialized discipline. Relationship may exist between subjects taught in primary school.

as teachers, we tend to wrap up subjects into neat little 'boxes'. We label those 'boxes' reading, social studies, physical education... and so on. But in fact, these subjects overlap. For example, the ability to think in a scientific way is useful in many other subjects. So, when you have the opportunity, try to relate the subjects to each other on the time-table. Projects are often a useful way of doing this (Young, 1979: 55).

It is in this regard that the researchers investigated the relationship between performance of primary school pupils in cultural and creative art and their performance in basic science and technology in Sokoto state.

There has been reports that primary school children are under performing in basic science and technology, as studied by Osafehinti and Gyuse in Okpongete (1992); Gorard, Meece and Jones (1996), Kathryn and Ellen (2000); Gorard, Rees and Salisbury (2001). It is the objective of these research to find out relationship between children performance in Basic Science and Technology (BST) and their performance in Cultural and Creative Art (CCA) in primary schools of Sokoto state

Due to the nature of the study, research question was raised as guide to the conduct of the research, thus 'is there any relationship between children performance in Basic Science and Technology (BST) and their performance in Cultural and Creative Art (CCA) in primary schools of Sokoto stat?'. Research hypothesis was developed and tested at .05 level of significance; There is no significant relationship between children performance in Basic Science and Technology (BST) and their performance in Cultural and Creative Art (CCA) in primary schools of Sokoto state.

The study was limited to some selected public primary (Basic) schools from the four educational zones of State Universal Basic Education Board (SUBEB) in Sokoto state. A total of 12 schools where CCA is taught were selected for the study. The limitation is as a result of the preresearch information gathered, that many primary schools in the study area do not teach cultural and creative art, some due to lack of specialized teachers, others due to lack of interest.

Literature is scarce in this relatively new area of study, however available literature is reviewed in the following areas:

\section{Comparison of Cultural and Creative Art and, Basic Science and Technology Curriculum in the 9-years Basic Education Curricula for Primary 4-6}

Examining the curriculum document of the two subjects closely, The researcher observes so much in common in the themes and topics that relate to Primary 4, Theme 4, Characteristics of Values in Cultural and Creative Arts; Hard work, Honesty, Precision, Creativity (which is not found in the Basic Science and Technology curriculum themes and topics). On the other hand the researcher still observes commonality in primary 4, theme 1 and 2 of the Basic Science and Technology Curriculum "Measurement; Length, Breadth, Area of object, Time" and, "Soil constituents, Air, Water, Leaf litters, Dead and living Animals; Water; Evaporation, Condensation;" which were not featured in the Cultural and Creative Art Curriculum for primary 4-6. A deep study in the curriculum will make one observe many missing links between the related curricula of the two subjects.

\section{Pupils performance in Basic Science and Technology, and in Cultural and Creative Art}

Osafehinti and Gyuse in Okpongete (1992), Oyedapo (2007) described a growing index of seemingly lack of interest and poor performance by students in science subjects at school certificate levels which is not unconnected with the foundation level (primary school). As a result, 
many Nigerians are illegible for science programmes beyond the certificate level. Okpongete (1992) described irrelevant science curricula as the cause of poor performance of children in science at various levels. Akinmade and Gyuse in okpongete (1992), Jessica (2010), NZCERD (2009), Sandra (2006), Kathryn and Ellen (2005) found that many children under achieved in science. Sandra (2006) reported that Art is critical to children performance in other subjects. In a similar study by Kathryn and Ellen (2005) Arts participation and SAT scores are correlates.

\section{Methodology}

The study used the 'Correlational Research Design', which is one of Descriptive Research Designs that describes an existing relationship between variables. "A Correlational study describes the degree to which two or more quantitative variables are related, and it does so by the use of a correlation coefficient" (J ack and Norman, 2000). However there is no manipulation of variables in Correlational research. Test performances in BST and CCA are the two variables studied in this research, they are termed Criterion and Predictor Variables. BST score is a predictor variable, while performance in CCA is the criterion variable in these study.

The population of the study consist of all primary six pupils in public schools in the study area (Sokoto state). However, there were 1674 total enrolment of class six pupils for the year of data collection (2011/2012 academic session) in the sampled schools of the four educational zones of SUBEB in Sokoto state (see FME, 2010/2011). Among the 1698 Government approved public schools in Sokoto State, twelve (12) primary schools were selected using 'Simple Random Sampling Method' for the study, the selection was justified because of the fact that many primary schools in the state do not teach CCA, thus the researcher selected only schools that teach CCA. The research is limited to public schools, three schools each from the four (4) SUBEB zones in the state. The researcher selected primary six as target for the study purposively, Thirty (30) pupils, twenty males and ten females were selected by 'Hat-draw' method in each of the selected schools for the study, the selection was justified by average number of children per class (48 pupils) and the ratio of male and female gender in the schools. A total sample of three hundred and sixty (360) pupils were used for the study (CCA and BST).

Completion and multiple choice performance tests items were developed by the researcher and employed for the study. The tests were constructed with reference to Onafowakan (2004) Primary Science Topics Skills/Activities; Victor and Lambert (1975) Measurement of Creativity in Art. These are in compliance with the National Board for Education Measurement (NBEM), National Examination Council (NECO): 1994, 2000, and 2003 National Common Entrance Examination into secondary schools. The items are also in cognizance with the National Policy on Education year 6 (vi) syllabus, scheme of work and curriculum, developed by the National Educational Research and Development Council (NERDC, 2007). There are two instruments administered for the study: Performance Tests in CCA and in BST. The tests were administered to the pupils and the scripts were collected and marked by the researcher, and the mean scores were compared thereafter. The instruments were also validated by experts in science education. Pearson Product Moment Correlation Coefficient was used to find correlation of the split half result scores. Spearman-Brown prophecy formula was also used to get the reliability of the instruments after the pilot testing of the instruments, hence 0.78 and 0.86 reliability $(r)$ co-efficient was established for CCA and BST instruments respectively, at .05 level of significance.

\section{Analysis and Results}

The analysis of data for research hypotheses that guided this study was accomplished by using the mean, standard deviation, Pearson Product-moment correlation co-efficient $(r)$ and t-Test. $r$ was used to analyze the hypothesis. $\mathbf{r}$ is a parametric statistic that measures relationships. Data was processed and analyzed electronically via Statistical Package for Social Science (SPSS, $16^{\text {th }}$ Version). 
The data obtained in this research is here presented and analyzed in tables and hypothesis tested accordingly.

There is no significant relationship between children performance in Basic Science and Technology (BST) and their performance in Cultural and Creative Art (CCA) in primary schools of Sokoto state.

Table: Showing relationship between children performance in Basic Science and Technology (BST) and their performance in Cultural and Creative Art (CCA) in primary schools of Sokoto state.

\begin{tabular}{|c|c|c|c|c|c|c|}
\hline Variable & $\mathbf{N}$ & $\overline{\mathbf{X}}$ & SD & d & Cal-r & $\begin{array}{l}\text { Crit-r } \\
\text { Decision }\end{array}$ \\
\hline BST & 360 & 9.07 & $\begin{array}{l}3.782 \\
358\end{array}$ & .487 & & $\begin{array}{l}.195 \mathrm{Hol} \\
\text { rejected }\end{array}$ \\
\hline
\end{tabular}

The table shows that with mean score of 9.07 and standard deviation of 3.782 in BST, and mean score of 7.40 and standard deviation of 2.551 in CCA, the correlation between BST and CCA scores of children ( $r$-cal .487 > r-crit .195) is significant at .05 level and degree of freedom 359, and with a calculated $r$ value of .487 less than .195 critical $r$ value, Null hypothesis ( $\mathrm{Ho}$ ) is rejected, meaning that there is significant relationship between BST and CCA mean scores of children in primary schools of Sokoto state. Further study of the coefficients of correlation reveals that children have higher mean scores in BST than in CCA $(9.07>7.40)$.

\section{Discussion}

Hypothesis (HO) was tested and found that pupils performance in Basic Science and Technology (BST) and their performance in Cultural and Creative Art (CCA) are related significantly. Critical $r$ value is less than calculated $r$ value $(.195<.487)$, Hol is rejected. In other words children score more in BST than in CCA. This finding may not be unconnected to Oyedeji and Alausa (1994) who observed primary school teachers preference for science and mathematics among other school subjects in Ogun state of Nigeria. Ibrahim (2008) reported on 'understanding the nature of science learning at primary school level in Nigeria as directed in recent years, is making progress in providing children with aptitude in science and its application and making others scientifically and technologically innovative and literate'. Kathryn and Ellen (2000), mention that arts participation and Standard Achievement Test (SAT) scores are related. Although the research discovered average under achievement in BST which is related to Gyuse and Okpongete (1992). However, this is contrary to Oyedapo (2007), NZCERD (2009), Sandra (2006) and Jessica (2010) who maintained that children in their case study schools identified arts as one of their favorite subjects in the United States (US). BST is now observed to be the favorite subject of children in this research in primary schools of Sokoto state.

\section{Summary of Finding}

The major finding in this research is here summarized thus:

There is significant relationship between pupils performance in BST and their performance in CCA in primary schools of Sokoto state, even though pupils perform more in BST than in CCA. 


\section{Conclusion}

In conclusion the researcher realizes that there is significant relationship between performance of pupils in Basic Science and Technology (BST) and their performance in Cultural and Creative Art (CCA) in the sampled primary schools of this study in Sokoto state. Children perform more in BST than in CCA. On gender and performance, although male gender out-perform the female gender in BST performance test, but the difference is not significant.

\section{Implications of the Study}

The study implies that performance of children in Basic Science and Technology influences their performance in Cultural and Creative Art

\section{Recommendation}

By the conduct of this research, the researcher recommend that:

Relevant authorities such as inspectors, supervisors and other education regulatory agencies shall look in to the cause effect of the relationship of performance and achievement of children in BST, CCA and such other subjects taught at primary school.

\section{Suggestions for Further Research}

The researcher suggests that further study shall be carried out in the following areas:

1. Other factors that improve the achievement and performance of children in BST (primary science)

2. Cause effects of the relationship between pupils performance and achievement in BST and in CCA in lower basic education and such other levels and subjects.

\section{References}

Akinmade \& Gyuse in E.A, Okpongete (1992). Toward Creative Science Teaching And Learning in West African Schools. Catholic Mission Press, Cape coast, Ghana.

Federal Republic of Nigeria (2004). National Policy on Education (4 ${ }^{\text {th }}$ Edition) Abuja: NERDC press.

Federal Ministry of Education (FME, 2010/2011). Schools Census Forms, Pre-primary and Primary Education. Public Schools.

Gorard, S. ,Rees, G. \& Salisbury, J.(2001). Investigating The Patterns of Differential Attainment in Boys and Girls at School (updated). British Educational Research Journal. 19, 403-426

Ibrahim, B. (2000). Visual Arts made Easy, for Schools and Colleges. Lagos: Movie publishing Company Limited, Nigeria. 1-33.

Ibrahim, N.T. (2008). The Impact of Teacher Qualifications on Children Achievement in Primary Science: A Study of Sokoto South Local Government Education Authority Sokoto. An unpublished M.Ed. Science Education Dissertation submitted to the Department of Science and Vocational Education, UDU, Sokoto, Nigeria.

Jack, R.F. and Norman, E. W.(2000). How to Design and Evaluate Research in Education(4 $4^{\text {th }}$ Edition). McGraw-Hill Higher Education. A Division of the McGraw-Hill Companies. Pp. 359.

J essica, S. (2010). Primary Pupils' Science Knowledge at Lowest Level Since 1999. www.guardian.co.uk, Tuesday10August 201011.50BST

Kathryn,v. \& Ellen, W. (2005). SAT Scores of Students Who Study the Arts: What we Can and Cannot Conclude about the Association. Total Group Profile Report. Fall 2000.

National Assessment of Educational Progress (NAEP).(2007). America's High School Graduates. Results from the 2005 NAEP High School Transcript Study. NCES No.

Nigerian Educational Research and Development Council (NERDC) (2007). 9-year Basic Education Curriculum. Basic Science \& Technology for Primaries 4-6. 
New Zealand Center for Educational Research and Development (NZCERD, 2009). A Focus on Science Achievement. Research Division

Onafowakan, B.A.O. (2004). Primary Science: A Source of Child Friendly Environment, Journal of Early Child Hood Association in Nigeria. 2(2), 79-102

Okpongete, E. A. (1992). Toward Creative Science Teaching And Learning in West African Schools. Catholic Mission Press, Cape coast, Ghana. Pp. 1.

Osafehinti O.A in Okpongete, E.A. (1992). Toward Creative Teaching And Learning in West African Schools. Catholic Mission Press, Cape coast, Ghana. Pp. 14-15.

Oyedapo, A.D (2007). Utilizing the Benefits of Information Technology In Improving Students' Interest and Achievement In Science Technology and Mathematics. The ScienceTeacher Today. Journal Of School of Sciences, F C E, Eha-Amufu. 4 (1), 145-149

Oyedeji, O. A. \& Alausa, T. A (1994). Primary School Teachers Preference for Science and Mathematics Among other School Subjects. A case study of Ogun state. The Nigerian Teacher Today, Journal of Teacher Education. 2 (1), 48-57

Sandra, S. R. (2006). Critical Evidence: How the Arts Benefit Student Achievement. National Assembly of State Arts Agencies in Collaboration with the Arts Education Partnership. www. nasaa-arts.org Retrieved 5/10/2012

Statistical Package for Social Sciences (SPSS)(2007). SPSS for Windows, Version 16, Team EQX, $6^{\text {th }}$ birthday.

www.spss.com

Victor, L. and Lambert, W. (1975). Creative and Mental Growth (6 $6^{\text {th }}$ edition). Macmillan Publishing Co. Inc. New York.

Young, B.L (1979). Teaching Primary Science. Longman Group Limited, Longman House, Essex England. 